\title{
PENGARUH MODEL PEMBELAJARAN DISCOVERY LEARNING DENGAN ALAT PERAGA SEDERHANA TERHADAP KEMAMPUAN METAKOGNITIF
}

\author{
Uum Masitoh $^{1)}$, Ondi Suganda ${ }^{2)}$, Rahma Widiantie ${ }^{3)}$ \\ ${ }^{1}$ Pendidikan Biologi, FKIP, Universitas Kuningan \\ ${ }^{2}$ Pendidikan Biologi, FKIP, Universitas Kuningan \\ Email :ondi.suganda @uniku.ac.id \\ ${ }^{3}$ Pendidikan Biologi, FKIP, Universitas Kuningan \\ Email :rahma.widiantie@uniku.ac.id
}

APA Citation: Masitoh, U., Suganda, O., \& Widiantie, R. (2019). Pengaruh Model Pembelajaran Discovery Learning Dengan Alat Peraga Sederhana Terhadap Kemampuan Metakognitif. Quagga: Jurnal Pendidikan dan Biologi, 11(1), 27-33. doi: 10.25134/quagga.v11i1.1510.

Received: 28-11-2018

Accepted: 22-01-2019

Published: 24-01-2019

\begin{abstract}
Abstrak: Proses pembelajaran yang tidak bervariasi menyebabkan siswa kurang mengembangkan keterampilan berpikirnya terutama kesadaran metakognitifnya. Akibatnya siswa kesulitan dalam memahami konsep yang diajarkan pada hal proses pembelajaran dihubungkan dengan masalah nyata dan sering ditemukan dalam kehidupan sehari-hari. Penelitian ini bertujuan untuk mengetahui pengaruh model pembelajaran discovery learning dengan alat peraga sederhana terhadap kemampuan metakognitif siswa. Populasi penelitian ini adalah seluruh siswa kelas VIII dan sampel yang digunakan sebanyak 62 siswa yang diambil secara acak menggunakan teknik cluster random sampling. Desain penelitian ini adalah Pretest-Posttest Control Only Design. Teknik pengumpulan data yang digunakan Metacognitive Awareness Inventory (MAI) dan tesuraian kemampuan kognitif siswa. Hasil penelitian menunjukkan ada perbedaan yang signifikan antara siswa kelas eksperimen pada hasil tes MAI dengan menggunakan model discovery learning dengan alat peraga sederhana. Kesadaran metakognitif siswa kelas eksperimen dikategorikan sangat baik dan siswa kelas control hasilnya kategori baik. Hasil uji t menunjukan adanya perbedaan yang signifikan kemampuan kognitif siswa antara siswa kelas eksperimen dengan menggunakan model discovery learning dengan alat peraga sederhana. Penerapan model pembelajaran discovery learning dengan alat peraga sederhana berpengaruh terhadap kemampuan metakognitif siswa.
\end{abstract}

Kata Kunci : Alat Peraga Sederhana, Kemampuan Metakognitif, Model Discovery Learning.

Abstract: Learning processes that do not vary cause students to develop their thinking skills, especially their metacognitive awareness. As a result students find it difficult to understand the concepts taught even though the learning process is associated with real problems and often found in everyday life. This study aims to determine the effect of discovery learning learning models with simple teaching aids on students' metacognitive abilities. The population of this study was all eighth grade students and the sample used was 62 students taken randomly using cluster random sampling technique. The design of this study is the Pretest-Posttest Control Only Design. The data collection technique used is the Metacognitive Awareness Inventory (MAI) and a description of the students' cognitive abilities. The results showed that there were significant differences between the experimental class students on the MAI test results using discovery learning models with simple teaching aids. Metacognitive awareness of the experimental class students was categorized very well and the control class students were in the good category. The results of the t test show a significant difference in the cognitive abilities of students between the experimental class students using the discovery learning model with simple teaching aids. The application of discovery learning learning models with simple teaching aids influences students' metacognitive abilities.

Keywords : Simple Props, Metacognitive Abilities, Models Discovery Learning.

\section{PENDAHULUAN}

Melalui metakognisi pikiran dapat dijaga, direncanakan, dan dikendalikan. Metakognitif menekankan kemampuan berpikir pada tingkat yang lebih tinggi melampaui berpikir normal dalam merefleksikan berpikir itu sendiri. Dalam konteks pembelajaran, siswa mengetahui bagaimana untuk belajar, mengetahui kemampuan dan modalitas belajar yang dimiliki, dan mengetahui strategi belajar terbaik untuk belajar efektif. Siswa dengan kesadaran metakognitifnya sadarakan kelebihan dan 
keterbatasannya dalam belajar. Artinya, ketika siswa mengetahui kesalahannya, siswa sadar akan pentingnya mengakui bahwa mereka salah, dan berusaha untuk memperbaikinya sehingga akan menunjang keberhasilan dalam pembelajaran dan memorinya.

Berdasarkan pengalaman dan hasil pengamatan di SMP Negeri 1 Cibingbin, ditemukan permasalahan yaitu proses pembelajaran yang dilakukan masih berupa ceramah atau kegiatan pembelajaran masih berpusat pada guru (Teacher-Centered Learning), belum menggunakan pendekatan saintifik dan belum mengaplikasikan model pembelajaran yang berbasis pada masalah sehingga siswa merasa bosan dan ada beberapa yang tidak memperhatikan pada saat pembelajaran berlangsung. Guru juga tidak member siswa kesempatan untuk mengembangkan ide-ide dan gagasan yang dapat melatih kemampuan berpikir (bernalar) mereka. Padahal kurikulum yang dipakai di sekolah tersebut merupakan kurikulum 2013. Hal tersebut menyebabkan peserta didik kurang terlatih dalam keterampilan berpikirnya dan berakibat pada rendahnya hasil belajar mereka yaitu masih banyak siswa yang tidak dapat menyelesaikan tugas dan mendapat nilai dibawah kriteria ketuntasan minimum yaitu 72 .

Permasalahan lain yang ditemukan disekolah tersebut adalah sarana dan prasarana tidak mendukung dan belum adanya media pembelajaran sehingga untuk proses pembelajaran perlu dilakukan inovasi dengan membuat media sederhana berupa alat peraga. Alat peraga adalah alat/media yang dipakai untuk memudahkan memahami suatu konsep secara tidak langsung (Sisdiknas, 2001). Keunggulan dari proses pembelajaran menggunakan alat peraga sederhana system pernapasan manusia dapat meningkatkat kemampuan siswa dalam memahami konsep sistem pernapasan manusia, membuat siswa lebih aktif, menyenangkan serta kegiatan pembelajaran menjadi lebih hidup, sehingga siswa akan merasa termotivasi untuk belajar biologi.

Dalam proses pembelajaran guru mempunyai peran yang sangat penting, oleh karena itu diharapkan guru memiliki model mengajar yang baik dan mampu memilih model pembelajaran yang tepat, sehingga siswa mampu menguasai kompetensi-kompetensi yang ditetapkan dalam pembelajaran yang dilakukan. Penguasaan kompetensi oleh siswa dapat dibantu dengan penggunaan model belajar yang sesuai dengan materi yang diberikan, sehingga guru tidak hanya berfungsi sebagai sumber informasi yang setiap saat menjadi acuan siswa, tetapi ia juga harus berperan sebagai perangsang dalam pengembangan minat siswa dalam mencari informasi secara mandiri.

Discovery Learning menurut Schunk, 2012 dalam (Cahyani, 2015) merupakan model pembelajaran yang memerlukan pengajuan pertanyaan, permasalahan, maupun situasi yang membingungkan untuk diselesaikan oleh siswa dan dorongan untuk membuat jawaban yang intuitif saat siswa merasa tidak yakin. Kelebihan model Discovery Learning yakni mengacu pada penguasaan pengetahuan untuk diri sendiri yang diperoleh melalui proses mencari, mengolah, menelusuri, dan menyelidiki.

Discovery Learning sesuai untuk mata pelajaran Biologi karena ada beberapa materi yang berkaitan dengan sistem yang terjadi pada manusia yang bersifat abstrak dan berhubungan dengan fungsi dan proses yang kompleks, sehingga banyak permasalahan yang harus dicari, diolah, di telusuri, di selidiki dan dipelajari. Oleh karena itu dengan Discovery Learning dapat menggali untuk memperoleh pengetahuan yang esensial dari materi pelajaran, melatih berpikir tingkat tinggi termasuk didalamnya bagaimana belajar (metakognitif) dan membuat siswa menjadi pembelajar mandiri.

\section{METODOLOGI PENELITIAN}

Metode penelitian yang digunakan pada penelitian ini yaitu Quasi Experimental Design. Desain penelitian yang dipakai adalah PretestPosttest Only Contro Design.

Populasi subyek penelitian ini adalah siswa kelas VIII SMP Negeril Cibingbin tahun ajaran 2016-2017 dengan jumlah populasi sebanyak 224 siswa. Teknik pengambilan sampel yang digunakan adalah Cluster random sampling (areasampling). Yang diambil sebagai sampel berjumlah 62 siswa yang terdiri dari kelas eksperimen menggunakan model Discovery Learning dengan alat peraga sederhana dan kelas kontrol menggunakan model pembelajaran Inquiry. Alat ukur yang dipakai dalam penelitian ini adalah angket MAI (Metacognitive Awareness Inventory) untuk mengukur kesadaran metakognitif siswa dan test uraian untuk mengetahui kemampuan kognitif siswa. Setelah data diperoleh maka dilakukan analisis secara deskriptif dan analisis statistik menggunakan uji 
Quagga: Jurnal Pendidikan dan Biologi

Volume 11, Nomor 1, Januari 2019

T-tes dan uji Gain.Uji statistik dilakukan pada taraf signifikansi $5 \%$.

\section{HASIL DAN PEMBAHASAN}

Sebelum melakukan proses pembelajaran dengan menerapkan model yang telah ditentukan, dilakukan pretest pada kelas eksperimen dan kelas kontrol untuk mengetahui seberapa besar pengetahuan siswa mengenai konsep yang akan dipelajari.

Tabel1.Hasil Uji t Pretest

\begin{tabular}{ccccc}
\hline $\begin{array}{c}\text { Kelom } \\
\text { pok yang } \\
\text { Diuji }\end{array}$ & t hit & Db & t tab & $\begin{array}{c}\text { Kesimpu } \\
\text { lan }\end{array}$ \\
\hline $\begin{array}{c}\text { Eksperi } \\
\text { men dan } \\
\text { kontrol }\end{array}$ & 15,35 & 60 & 1,671 & $\begin{array}{c}\mathrm{H}_{1} \\
\text { diterima, } \\
\mathrm{H}_{0} \\
\text { ditolak. }\end{array}$ \\
\hline
\end{tabular}

Berdasarkan table 1 , nilai $t_{\text {hitung }}>t_{\text {tabel }}$ $(15,35>1,671)$, maka $\mathrm{H}_{1}$ diterima artinya ada perbedaan kemampuan kognitif siswa kelas eksperimen dan kelas control pada konsep system pernapasan dengan menggunakan model discovery learning dengan alat peraga sederhana.

Kemudian setelah masing-masing kelas sampel diberi perlakuan, kedua kelas sampel melakukan posttest untuk mengukur apakah terdapat peningkatan kemampuan kognitif terhadap konsep yang dipelajari. Karena pada saat dilakukan perhitungan hasil pre test menunjukkan terdapat perbedaan yang signifikan, maka dilakukan uji gain untuk mengetahui selisih nilai post test dan pretest antara kelas eksperimen dan kelas kotrol.

Berdasarkan nilai $t_{\text {hitung }}>t_{\text {tabel }}(21,96>1,671)$, maka $\mathrm{H}_{1}$ diterima artinya model pembelajaran discovery learning dengan alat peraga sederhana berpengaruh terhadap kemampuan kognitif siswa kelas VIII pada konsep sistem pernapasan. Hal tersebut sesuai dengan penelitian yang dilakukan oleh Windasari, dkk. (2016) bahwa model discovery berpengaruh terhadap peningkatan kesadaran metakognitif dan hasil belajar kognitif siswa.

Berdasarkan analisis hasil penelitian menunjukkan bahwa terdapat peningkatan hasil belajar pada kelas eksperimen setelah dilakukan pembelajaran dengan menggunakan model pembelajaran discovery learning.

Dalam prakteknya, penelitian dengan model pembelajaran discovery learning tidak disampaikan konsep- konsep pembelajaran secara
p-ISSN 1907-3089, e-ISSN 2651-5869

https://journal.uniku.ac.id/index.php/quagga

langsung, melainkan siswa didorong untuk mandiri, mencoba-coba dan guru hanya membimbing siswa dimana ia diperlukan sehingga model tersebut mampu melatih keterampilan berfikir siswa.

Pembelajaran menggunakan model discovery learning membuat siswa lebih aktif, dapat menguasai konsep-konsep pembelajaran yang disampaikan, selain itu konsep tertanam dengan baik pada siswa karena siswa memahami konsep dan tidak sekedar menghafal, siswa mampu bekerja sama dalam kelompok, berbagi, saling member pendapat, saling membantu dalam mengerjakan tugas, dapat berkomunikasi dan berinteraksi dengan baik sehingga materi pembelajaran dapat dikuasai oleh siswa.

Dalam penelitian ini, penerapan model pembelajaran discovery learning dilakukan inovasi dengan membuat media sederhana berupa alat peraga mekanisme pernapasan. Alat peraga tersebut dibuat dari bahan yang sudah tidak dipakai yang dirancang secara sederhana dengan alat-alat yang mudah didapat di lingkungan dan tidak memerlukan biaya yang besar dalam pembuatannya seperti balon, botol plastik, plastik, sedotan, karet gelang, dan solatip. Alat peraga dari bahan bekas yang dirancang sedemikian rupa tersebut dapat mewakili beberapa organ respirasi, mekanisme respirasi serta kondisi paru-paru pada saat manusia menghirup dan menghembuskan napas.

Berdasarkan penelitian, siswa dalam kategori sangat aktif dalam kegiatan pembelajaran menggunakan alat peraga sistem pernapasan manusia. Hal tersebut ditunjukkan pada saat pembelajaran siswa aktif berinteraksi dengan guru maupun siswa lainnya dan siswa mengikuti pembelajaran sesuai yang diharapkan guru.

Selain meningkatnya hasil belajar siswa, penerapan model discovery learning dengan alat peraga sederhana berdampak pula pada kemampuan metakognitif siswa.

Beberapa tahapan pada model pembelajaran discovery diantaranya adalah Stimulation (Pemberian Rangsangan), Problem Statement (Identifikasi Masalah), Data Collection (Pengumpulan Data), Data Processing (Pengolahan Data), Verification (Pembuktian), dan Generalization (Penarikan Kesimpulan).

Pada proses pembelajaran,siswa bersama dengan anggota kelompoknya melakukan kegiatan demonstrasi, diskusi dan presentasi. Masing-masing kelompok diberikan Lembar Kerja Siswa yang didalamnya memuat beberapa 
kegiatan terkait dengan konsep yang akan dibahas yaitu mengenai mekanisme pernapasan dan frekuensi pernapasan. Selain LKS, pada kegiatan demonstrasi siswa juga difasilitasi dengan alat peraga sederhana.

1.Stimulation (Pemberian Rangsangan), tahapini berfungsi untuk menyiapkan kondisi interaksi belajar yang dapat mengembangkan dan membantu siswa dalam mengeksplorasi bahan. Tahap stimulation ini pada indikator metakognitif merupakan planning (perencanaan) dimana tahapan awal menetapkan tujuan dan pengalokasian belajar terlebih dahulu.

Adapun tujuan dari proses pembelajaran pada saat penelitian yaitu: Melalui kegiatan demonstrasi, diskusi, dan demonstrasi siswa mampu menganalisis perbedaan proses inspirasi dan ekspirasi pada pernapasan perut dan pernapasan dada pada manusia serta mampu mendeskripsikan faktor-faktor yang mempengaruhi frekuensi pernapasan.

Pada saat pembelajaran siswa melakukan kegiatan yang sesuai dengan tujuan pembelajaran yang sudah ditetapkan. Pada tahap ini siswa dihadapkan pada sesuatu yang menimbulkan kebingungan agar muncul keinginan untuk menyelidiki sendiri yaitu memberikan stimulation dengan mengajukan pertanyaan-pertanyaan sehingga menghadapkan siswa untuk mengerahkan pemikirannya dan mendorong eksplorasi.

2. Problem Statement (Identifikasi Masalah), memberikan kesempatan siswa untuk mengidentifikasi dan menganalisis permasalahan yang dihadapi oleh siswa untuk selanjutnya dirumuskan dalam bentuk pernyataan (statement) sebagai hipotesis atas pertanyaan yang diajukan pada saat stimulation. Pada proses pembelajaran, siswa melakukan kegiatan demonstrasi sesuai dengan perintah pada LKS terkait dengan konsep mengenai mekanisme pernapasan dan frekuensi pernapasan. Kemudian bersama dengan anggota kelompoknya melakukan idenifikasi kembali berdasarkan kegiatan demonstrasi yang telah dilakukan.

Identifikasi Masalah adalah tahap permulaan, dalam indikator metakognitif tahap ini termasuk kedalam perencanaan (planning) dan pengetahuan deklaratif (declarative knowledge). Pada saat pembelajaran siswa melakukan dugaan atau perkiraan sesuai dengan pemikiran dari pengetahuan yang mereka miliki dimana mereka perlu untuk memproses sebelum menggunakan pemikiran kritis yang terkait dengan topic tersebut.

3.Data Collection (Pengumpulan Data), mengumpulkan berbagai informasi yang relevan. Pada proses pembelajaran selain membaca literature siswa juga melakukan uji coba sendiri menggunakan alat peraga sederhana yang disediakan oleh guru. Alat peraga sederhana yang telah tersedia membantu memudahkan mereka dalam melakukan analisis dan memperkuat konsep terhadap demonstrasi yang telah dilakukan. Pada tahapan ini siswa belajar secara aktif untuk menemukan sesuatu yang berhubungan dengan permasalahan yang dihadapi.

Uji coba dengan menggunakan alat peraga melatih pengetahuan deklaratif, prosedural, dan kondisional dan dalam pemantauan terhadap pemahaman, strategi mengelola informasi dan strategi perbaikan. Pada tahap ini siswa melakukan suatu prosedur atau proses untuk mencapai tujuan belajar. Adanya uji coba dan diskusi kelompok menjadikan siswa lebih aktif. Selain itu juga belajar dengan sesama teman memudahkan untuk saling bertukar pikiran dan pendapat sesuai pengalaman yang didapat dalam pengamatan. Hal ini ditandai dengan keantusiasan siswa dalam mencoba alat peraga yang digunakan dan pemerosesan informasi mereka menjadi lebih cepat. Dari kegiatan tersebut siswa (mengetahui) "tentang, apa atau bahwa" yaitu beberapa organ respirasi apa saja yang mewakili dari alat peraga dan memahami mengenai mekanisme inspirasi dan ekspirasi, serta faktor yang mempengaruhi frekuensi pernapasan. Pada tahap ini juga siswa juga menyadari kesalahan kinerja mereka pada saat demonstrasi khususnya yang berkaitan dengan kegiatan untuk mengetahui faktor-faktor yang mempengaruhi frekuensi pernapasan, tidak sedikit kelompok satu dengan kelompok yang lain terdapat perbedaan pemerolehan konsep, namun mereka mampu memperbaiki pemahaman mereka setelah mendapatkan data relevan.

4. Data Processing (Pengolahan Data), kegiatan mengolah data dan informasi yang telah diperoleh para siswa melalui demonstrasi dan uji coba yang dihubungkan dengan sumber relevan. Data processing akan membentuk konsep dan pengetahuan baru.

Pada tahap ini dilakukan kegiatan diskusi LKS untuk membahas demonstrasi dan uji coba yang telah dilakukan. Tahap ini melatih akan pengetahuan kondisional (conditiona knowledge) 
Quagga: Jurnal Pendidikan dan Biologi

Volume 11, Nomor 1, Januari 2019

dan strategi mengelola informasi (information management strategies). Pada proses pembelajaran mereka mampu menerapkan pengetahuan deklaratif dan prosedural dengan kondisi tertentu yang dihadapi dan selektif dalam memfokuskan/meringkas topik pembelajaran sehingga mereka dapat membedakan mana yang penting dan tidak penting untuk dipelajari.

5.Verification (Pembuktian), pemeriksaan secara cermat untuk membuktikan benar atau tidaknya dugaan/perkiraan yang ditetapkan dengan temuan alternative dihubungkan dengan hasil data processing. Pada tahap verification siswa mempresentasikan hasil diskusi kelompoknya masing-masing pada kelompok lain. Hal ini bertujuan agar siswa menggunakan lebih banyak kemampuannya sehingga mereka bisa lebih banyak mengerahkan pemikiran mereka selama pembelajaran karena selain menyampaikan hasil diskusi kelompoknya sendiri mereka juga harus mampu menjawab saat diberi pertanyaan dan menerima sanggahan jika terdapat perbedaan pemahaman konsep. Hal ini berarti tahap verification berhubungan dengan indicator metakognitif mengenai pemantauan terhadap pemahan (compherension monitoring) yaitu penilaian dari suatu pelajaran atau strategi penggunaan. Dengan demikian berarti berhubungan pula dengan strategi perbaikan (debugging strategis) dimana mereka mampu memperbaiki pemahan jika terdapat kesalahan.

6.Generalization (Penarikan Kesimpulan), penarikan kesimpulan dapat dijadikan prinsip umum dan berlaku untuk semua kejadian atau masalah yang sama. Dengan demikian berarti pada tahapan ini berhubungan dengan indikator evaluasi (evaluation) pada metakognitif, yaitu menganalisis kinerja secara keseluruhan dan efektivitas strategi setelah pembelajaran.

Semakin tinggi kesadaran metakognitif yang siswa miliki maka semakin tinggi pula dalam hal kemampuan kognitifnya. Siswa dengan kesadaran metakognitif yang tinggi terbukti menunjukkan adanya peningkatan hasil belajar dari kemampuan awal (pretest) ke setelah dilakukan proses pembelajaran (post test) pada kelas eksperimen. Hasil penelitian ini menunjukkan bahwa penerapan model pembelajaran discovery learning dengan alat peraga sederhana dapat meningkatkan kemampuan kognitif siswa.

Kesadaran metakognitif siswa diperoleh dari hasil tes Metacognitive Awareness Inventory (MAI) yang diberikan pada dua kelas yang di uji yaitu kelas eksperimen dan kelas kontrol. Angket
p-ISSN 1907-3089, e-ISSN 2651-5869

https://journal.uniku.ac.id/index.php/quagga

ini berisi 52 pertanyaan yang mengacu pada 8 komponen pengetahuan metakognitif. Menurut OLRC News, 2004; Schraw \& Moshman,1995 menyatakan bahwa komponen metakognisi terbagi menjadi pengetahuan tentang kognisi (knowledge about cognition) dan regulasi kognisi (regulation of cognition). Pengetahuan mengenai kognisi terdiri dari pengetahuan deklaratif (declarative knowledge), pengetahuan procedural (procedural knowledge) dan pengetahuan kondisional (conditional knowledge). Sedangkan regulasi tentang kognisi (regulation about cognition) terdiri dari: a) Perencanaan (planning), b) Strataegi mengelola informasi (information management strategies), c) Pemantauan terhadap pemahaman (comprehension monitoring), d) Strategi Perbaikan (debugging strategies), dane) Evaluasi (evaluation).

Tabel 2.Hasil Uji t Data Kesadaran Metakognitif

\begin{tabular}{ccccc}
\hline $\begin{array}{c}\text { Kelom } \\
\text { pok } \\
\text { yang } \\
\text { Diuji }\end{array}$ & thit & Db & t tab & $\begin{array}{c}\text { Kesimpu } \\
\text { lan }\end{array}$ \\
\hline $\begin{array}{c}\text { Eksperi } \\
\text { men dan } \\
\text { kontrol }\end{array}$ & 2,04 & 60 & 1,671 & $\begin{array}{c}\mathrm{H}_{0} \\
\text { ditolak, } \\
\mathrm{H}_{1} \\
\text { diterima }\end{array}$ \\
\hline
\end{tabular}

Berdasarkan table 2.diperoleh hasil bahwa $t_{\text {hitung }}>t_{\text {tabel }}$ yaitu 2,04>1,671, maka $\mathrm{H}_{0}$ ditolak dan $\mathrm{H}_{1}$ diterima, artinya ada perbedaan yang signifikan antara siswa kelas eksperimen dengan siswa kelas kontrol pada hasil tes MAI terhadap kesadaran metakognitif siswa pada kelas eksperimen dengan model pembelajaran discovery learning dengan alat peraga sederhana.

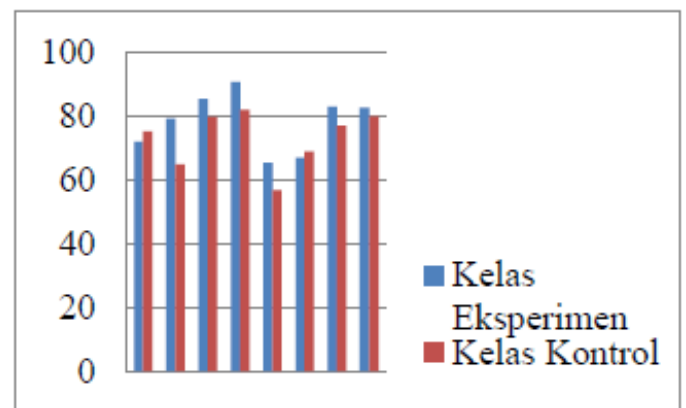

Gambar 1. Persentase Kesadaran Metakognitif Siswa

Presentase yang diperoleh indicator ini tidak seperti perolehan persentase pada indikator pengetahuan metakognitif yang lain yang menunjukan nilai persentase pada kelas 
eksperimen lebih tinggi dibandingkan pada kelas kontrol. Diantara semua indicato rpengetahuan metakognitif, terdapat dua indicator pada kelas eksperimen yang memiliki persentase rendah dibandingkan pada kelas control yaitu indikator pengetahuan deklaratif dan pemantauan terhadap pemahaman. Namun demikian, persentase pada kedua indikato rtersebut menunjukkan kriteria yang sama-sama baik, baik pada kelas ekperimen maupun pada kelas kontrol. Pada proses pembelajaran tidak sedikit siswa merasa kesulitan dalam menjawab soal uraian karena tidak mampu dalam menyerap informasi dengan baik dan pengetahuan mengenai konsep yang diajarkan masih rendah hal ini dapat dilihat pada hasil tes kemampuan kognitif bahwa tidak sedikit siswa yang perolehan tes pengetahuan kognitifnya tidak sesui dengan yang diharapkan. Menurut Corebima, 2009 dalam (Hadyzah, 2012) mengatakan bahwa penerapan macam strategi pembelajaran, misalnya strategi regulasi mandiri dapat melatih pebelajar untuk bicara kepada diri sendiri dan membuat pebelajar untuk selalu memantau dan meregulasi perilakunya sendiri. Siswa yang menerapkan strategi belajar dalam mengolah informasi baru dengan mengaktifkan pengetahuan awal meningkatkan pemahaman penilaian mereka sendiri.

Pembelajaran menggunakan permasalahan yang dihadirkan melalui lembar kerja siswa dapat memfasilitasi kemampuan metakognitif meliputi pengetahuan deklaratif, pengetahuan procedural, dan pengetahuan kondisional karena siswa dilatih untuk meregulasi pengetahuan yang telah diperoleh sebelumnya melakukan pemrosesan dan mengevaluasi untuk memecahkan permasalahan pembelajaran (Widiantie,2018)

Hasil rata-rata kesadaran metakognisi siswa sejalan dengan skor rata-rata penguasaan konsep. Artinya, apabila skor kesadaran metakognisi meningkat, maka skor pengetahuannya pun juga cenderung meningkat. Dapat disimpulkan dalam penelitian ini discovery learning memiliki potensi besar untuk mengembangkan dan meningkatkan kesadaran metakognitif siswa.

Hal ini berarti menujukan bahwa model Discovery Learning dengan alat peraga sederhana yang diterapkan mampu memfasilitasi dan membangun pengetahuan meta kognitif siswa menjadi lebih baik. Hal ini mendukung pernyataan metakognisi sebagai pengetahuan dan kesadaran tentang proses kognitif. Siswa perlu menyadari akan kelebihan dan kekurangan dari kemampuan kognitifnya dan berupaya mengorganisasikannya untuk diterapkan secara tepat dalam penyelesaian tugas atau masalah Kuntjojo, 2009dalam (Lestari, 2016).

\section{SIMPULAN}

Dari hasil penelitian dan analisis data yang telah dilakukan maka dapat disimpulkan bahwa penerapan model pembelajaran Discovery Learning dengan alat peraga sederhana berpengaruh terhadap kemampuan metakognitif siswa kelas VIII pada konsep sistem pernapasan. Dan ada perbedaan yang signifikan antara siswa kelas eksperimen dan kelas control pada hasil tes MAI. Ketercapaian keseluruhan indikator kesadaran metakognitif dikelas eksperimen berada dalam kategori sangat baik sedangkan dikelas kontrol memiliki kategori baik.

\section{REFERENSI}

Cahyani, M. Rizki, dkk. 2015. Pengaruh Model Pembelajaran Discovery Learning Terhadap Kemampuan Berpikir Logis Siswa Kelas X MIA SMA Muhammadiyah 1 Surakarta Tahun Pelajaran 2013/2014. Jurna Pendidikan Biologi [online]. Tersedia:http://jurnal.fkip.uns.ac.id/index.p hp/bio/article/download/7365/5139

[Diakses 16 Desember2016]

Hadyzah, Elys. 2012. Meningkatkan Kemampuan Metakognisi dan Hasil Belajar Biologi Siswa SMA PGRI 1 Punggur Melalui Penerapan Metode Inkuiri Terbimbing (Guide Inquiry). Bioedukasi [online].Tersedia:http://fkip.ummetro.ac.id/ journal/index.php/biologi/article/view/262 [Diakses 16 Juli 2017]

Lestari, H Nur. 2016. Hubungan Antara Pengetahuan Metakognitif dengan Kemampuan Pemecahan Masalah Melalui Model Problem Based Learning (PBL) pada Konsep Pencemaran Lingkungan di Kelas X [Skripsi] Program Studi Pendidikan Biologi Universitas Kuningan. Kuningan. (Tidak dipublikasikan)

Mailiana, Fina. 2015. Penerapan Model PBL (Problem Based Learning) untuk Meningkatkan Kemampuan Metakognitif Siswa pada Materi Pencemaran Lingkungan Kelas X diSMA Negeri 1 Cibingbin [Skripsi] Program Studi 
Pendidikan Biologi Universitas Kuningan. Kuningan. (Tidak dipublikasikan)

ORLC News. 2004. Metacognition [online] Tersedia:http:www.literacy.kent.edu/ohioe ff/resource.doc [18 Januari 2017]

Rahma Widiantie, Handayani Handayani. 2018. Kesadaran Metakognisi Dan Keterampilan Memecahkan Masalah Mahasiswa Melalui Pembelajaran Berbasis Masalah Dengan Penugasan Individu [online]. Jurnal Quagga vol.10 No.1 Januari 2018. Tersedia:https://journal.uniku.ac.id/ind ex.php/quagga/article/view/872. (diakses tanggal 3 januari 2017)

Wahjudi, Eko. 2015. Penerapan Discovery Learning Dalam Pembelajaran IPA Sebagai Upaya untuk Meningkatkan Hasil Belajar Siswa Kelas IX-I di SMP Negeri 1 Kalianget. Jurnal Lensa [online]. Tersedia: http://lensa.fkipunija.org/article/penerapandiscovery-learning-dalam-pembelajaranipa-sebagai-upaya-untuk-meningkatkanhasil-belajarsiswa-kelas-ix-i-di-smpnegeri-1-kalianget/ [Diakses 21 Februari 2017]

Windasari, Cut dkk. 2016. Pengaruh Model Guide Discovery Terhadap Kesadaran Metakognitif Dan Hasil Belajar Kognitif Peserta Didik Pada Materi Sistem Reproduksi Manusia Di Mas Babun Najah Banda Aceh [online]. Jurnal Biotik Vol.4 No.1 April 2016. Tersedia http://jurnal.arraniry.ac.id/index.php/bi otik/article/view/1072/842(diakses tanggal 3 januari 2017) 